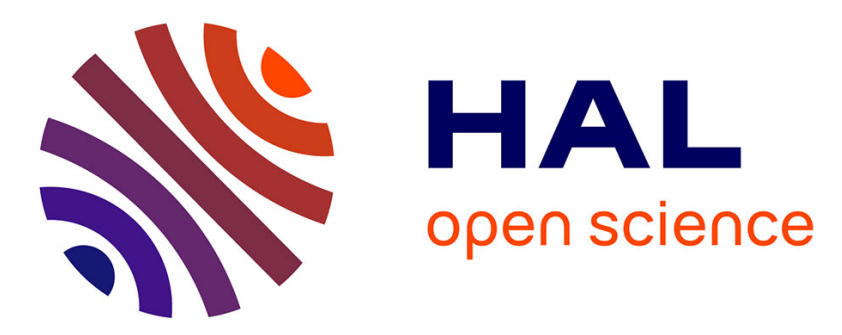

\title{
How risks and innovativeness influence the selection of partner in NPD alliances
}

Ioana Filipas Deniaud, François Marmier, Didier Gourc, Xavier Labaume

\section{To cite this version:}

Ioana Filipas Deniaud, François Marmier, Didier Gourc, Xavier Labaume. How risks and innovativeness influence the selection of partner in NPD alliances. 2017 IEEE 19th Conference on Business Informatics (CBI), Jul 2017, Thessaloniki, Greece. pp.62-69, 10.1109/CBI.2017.29 . hal-01666266

\section{HAL Id: hal-01666266 https://hal.science/hal-01666266}

Submitted on 15 Feb 2019

HAL is a multi-disciplinary open access archive for the deposit and dissemination of scientific research documents, whether they are published or not. The documents may come from teaching and research institutions in France or abroad, or from public or private research centers.
L'archive ouverte pluridisciplinaire HAL, est destinée au dépôt et à la diffusion de documents scientifiques de niveau recherche, publiés ou non, émanant des établissements d'enseignement et de recherche français ou étrangers, des laboratoires publics ou privés. 


\section{How risks and innovativeness influence the selection of partner in NPD alliances}

\author{
Ioana Filipas Deniaud \\ Strasbourg University \\ BETA laboratory \\ Strasbourg, France \\ deniaud@unistra.fr
}

\author{
François Marmier \\ Toulouse Univ, IMT Albi \\ Strasbourg Univ-BETA lab \\ France \\ marmier@mines-albi.fr
}

\author{
Didier Gourc \\ Toulouse University, IMT Albi \\ Industrial Engineering Center \\ Albi, France \\ gourc@mines-albi.fr
}

\author{
Xavier Labaume \\ Bee Engineering \\ 83 rue de la République \\ Lyon, France \\ xavier.labaume@bee-eng.fr
}

\begin{abstract}
Most often, if a new product is complex, a unique company doesn't have all the competences or means to achieve alone its development. In this case alliances must be formed to carry on the development project. However, alliances often meet difficulties in achieving their objectives. That is mainly due to difficulties of communication between partners, or to missing skills or means required to go further in the innovative development. To successfully overcome risks of collaboration dysfunction, an alliance must be created between partners able to communicate, presenting a complementarity in the project and being presenting a maximum of characteristics useful for the new project. This paper aims to increase our understanding of how to make alliance with the purpose of exploring the opportunities emerging from a partner innovativeness and risks management. We present an original model of alliance assessment composed by two partners intending to develop a particular innovative project. Based on this model, we propose a decision support system helping choosing firms for an alliance. A case study from the aeronautical industry is presented and results are analysed.
\end{abstract}

Keywords- alliances, design project, innovation, risk management

\section{INTRODUCTION}

Future success of a company often requires firms to regularly launch new products. In New Product Development (NPD) projects $[1,2,3]$ technological innovations and organizational changes such as alliances are needed to create fundamentally better products with new features and lower costs [4]. As the range of firm's technology expands, firms must learn. It needs more knowledge that can be difficult to acquire in the market. So firms seek collaboration with other firm to expend their knowledge and developed new products $[5]$.

The NPD is the result of a collaborative process in projectbased teams. These teams include members with different skills in a company or between companies working networked [6]. Companies almost never innovate alone [7, 8, 9, 10]. Therefore companies develop them by promoting effective collaborations with other firms having complementary assets [11] that add significant benefits for the NPD [12]. Companies can collaborate with research laboratories (public or private), start-ups or even competitors. In NPD project companies are looking to make alliances, each company offering specific expertise. NPD alliances are made for different purposes: gain access to knowledge, innovate, reduce costs, be more flexible $[13,14]$ and share technology [15].

Depending on project time the company that initiates the NPD project may seeks partners with a strong creative potential (especially in early phases - design: more exploratory) towards simple subcontractors (especially at the end of the project: production and commercialization - more exploitation). In the early phases of NPD a broad range of decisions need to be made even when little information is available [16]. In this paper we are especially interested in the exploration phases of NPD project, which imply creativity and generate innovation. Concerning this context Schiele [12] underlines that a typical problem is how to chose partners "who is more likely to fully understand the challenge, pose limited problems in collaboration and finally, who is the most likely to contribute with an innovative solution."

Despite the evident importance that partner's innovativeness plays during NPD partners/supplier selection $[11,12,17,18,19]$, there is limited research in the NPD area that focuses specifically on the concept of partner innovativeness, or which has defined the type of innovativeness that it considers, as part of the selection criteria. In this paper, partner innovativeness is investigated as a key feature of collaboration.

The manager objective is to enhance the performance of the NPD project. Generally, in a project, manager firstly specifies competences he needs to perform the project and then identifies partners having those competences. But when it comes to a new product development partners must also be able innovate and to develop new skills. Cuervo-Cazurra and Un [20] discussed different type of R\&D collaboration and their impact on innovation and NPD. In this context the project manager should be able to choose partners considering both partners' innovativeness and risks.

The selection of partners in inter-firm collaboration received little attention thus far in the voluminous literature on strategic alliances, innovation and risk management. In this paper we outline an approach of decision making in partners 
selection for NPD projects. Our approach considers partner innovativeness as the main features of collaboration.

This article is organized as follows. Firstly, theoretical background concerning innovation in alliances for NPD is done. Then factors influencing the selection of partners in inter-firm alliances for NPD are presented. We emphasis research limitations concerning partners' innovativeness influences in NPD alliances. Even a lot of research exists (case studies and empirical studies) almost all these studies have eschewed analytical analysis. In a second time we propose a model based on analytical approach. The model takes into account Alliance's innovativeness resulting from the partner selection itself. Finally, a case study from the aeronautical context illustrates our proposals.

\section{THEORETICAL BACKGROUND: INNOVATION IN ALLIANCES}

\section{A. NPD Alliances}

Since 1960 , in the R\&D alliances, firm increasingly prefer contractual partnership (nonequity alliance) to joint venture (equity alliance) [9]. To encourage innovation in NPD, companies have the choice between two types of non-equity alliances: unilateral alliance (R\&D contract...), bilateral alliance (joint $\mathrm{R} \& \mathrm{D}, \ldots$ ).

In unilateral alliance one partner provides founds to another partner for specified $\mathrm{R} \& \mathrm{D}$ development. In this case there are no knowledge sharing between partners and innovation level tends to be low.

In bilateral alliance, partners combine their knowledge and competences [21]. This re-combination can create new knowledge and innovations that will become the drivers of the alliance $[11,22]$. As underlined in introduction of this paper NPD project is related to innovation potential of the partners. For those reasons we are focusing on this kind of NPD alliance also called "co-development alliance" in Emden et al., [23] and defined as a "nonequity-based collaborative relationships enjoined by two or more firms to create value by integrating and transforming disparate pools of know-how related to new product or service development". It can be done in particular bilateral relations with the purpose of improvement in technology and know-how. For example agreements for joint $\mathrm{R} \& \mathrm{D}$, simultaneous engineering, joint design and/or technology. In this context partner selection became crucial.

\section{B. Innovation in NPD}

NPD projects can be range from incremental improvements to radical innovation. Firms pursuing innovation must maintain a balance between learning from external (exploration) and internal sources (exploitation). Too much exploitation is unlikely to lead to higher-order learning, whereas too much exploration is expensive and may produce many underdeveloped concepts and ideas [24].

In NPD, few firm's specific resources may lead to firm's competitive advantage $[25,26]$. In this way, an alliance is created by pooling the various resources of the partners.

Linnarsson et al. [27] highlight the tension between dynamics of innovation (demanding freedom and flexibility) and logic of alliance (demanding well defined situation). Indeed, in NPD alliance each partner has a dual function. On one hand, it ensures resource allocation function for the acquisition, the implementation and control of innovation (exploitation). In addition, the company provides resources creation function. In the same line Link \& Bauer [28] explains that NPD alliance is related to joint development of new product offering an opportunity for exploration [29]. This involves the sustained joint creation of property and knowledge for the partners, requiring them to bring in resources and work together on a constant basis [30]. Then NPD alliances should manage in the "dual logic of both partnering and innovation" [31].

\section{SELECTION OF PARTNERS}

More than $50 \%$ of innovative projects involve collaboration with external partners [32]. To realize those collaborative works a form of cooperative arrangement, named "strategic alliance", must to be done between partners [33].

Traditional selection criteria (cost, quality and delivery) do not characterize innovative and challenging NPD characteristics for an effective partner's selection [34]. Nevertheless, NPD projects involve technological uncertainty because firms don't know which technology to implement in their new product. Firms should select and collaborate with competent suppliers. Therefore, as it is observed in a wide literature review on selection suppliers/partners for NPD, the impact of technological uncertainty makes unclear how firms should select suppliers [35].

\section{A. Partner innovativeness}

In NPD alliance the choice of partners is determined in order to reach a potential for innovation $[11,12,17,19]$. Firm innovativeness is the potential capability and willingness of the partner to generate greater innovation value in a NPD alliance [19, 36, 37]. A wide literature concerns partners/suppliers selection and buyer-supplier relation in NPD alliances. Since partner's innovativeness is one of the key aspects of NPD collaboration, this section presents factors that contribute to partner's innovativeness.

In NPD alliances outcomes are difficult to define upfront and the resource transaction and capability development change the mutual innovation potential [31]. Nevertheless, in most cases, the innovations performance of the alliance is associated to the output of NPD project (new product or new technology).

Some authors emphasize the importance to select partner with high innovation potential. In this line authors speak about innovativeness [34], innovative capability [17, 38], research capability [39] creativity [23] or overlapping knowledge's [40]. But there is relatively little academic research on how measures partner innovativeness.

In the Resource-Based view literature, partner innovativeness is always correlated with product innovativeness and measured with an output variable: In Stuart et al. [41], partner's innovativeness was measured as the log of the total number of published patents of a local partnership in 
the previous year. Kalaignanam et al. [37] capture the innovativeness of the partner firms by counting the number of the patent citations received by the partner firms in the five years prior to the focal alliance date. Song et al [42], discuss suppliers implication in NPD and quantify the success of radical innovation by measuring the margin and sales. Nieto and Santamaria [43] use a control factor for the intensity of internal $R \& D$ (ratio of internal $R \& D$ expenditure to total sales) to explain the production of innovations. This measure is criticized by Adams et al [44] arguing that the high levels of R\&D intensity may simply masks innovation process inefficiencies.

This ex-ante evaluation is inefficient in partner selection. The partner selection should be made in the early stages of the project. A more interesting view is presented in KnowledgeBased Management literature: the potential for innovation derives from the cognitive distance between potential stakeholders. Nooteboom et al. [45] describes an inverse-Ushaped benefit-distance relationship that arises from the tradeoff between absorptive capacity [46] and novelty gain. These authors take into account the costs of alliance formation when these alliances are profitable. Nooteboom et al. [45] points out that "Novelty gain" increases with cognitive distance between partners. Innovation level is directly proportional with novelty gain. Alcantara et al. [47] pointed that firms with greater innovation capabilities possess cutting-edge knowledge about product technologies and have greater absorptive capacities to assess and assimilate externally generated technical knowledge. Higher absorptive capacity implies that partners have higher similarity to each other [48].

Cowan et al. develop a knowledge-based model of R\&D alliance in which firms seek to innovate [48]. The key assumption is that the strategic decision to forge an alliance is based both on similarities and complementarities of two participating firms. Complementarity between partners is also mentioned by several researches $[40,49,50,51]$. With a "risk management" point of view an alliance presents relational risks that are those regarding cooperation and performance risks that are those regarding future states of the alliance objectives. A well-designed alliance therefore permits by it self to minimise both relational risk end performance risk that tend to be high [52].

However, despite a literature presenting notions of similarity between partners leading to aptitudes to communicate and complementarity conferring to each partner a usefulness and a strong involvement in the project, there is a lack relative to the fact to combine these points with a vision of the requirement of the project (skills, means,...). The following section presents therefore presents our proposal to fill this lack.

\section{MODEL}

This work is focused on alliances between two partners. Several collaborations can be studied for a given innovative project. The choice of an alliance means an adaptation and appropriation of the project. Little account is taken of the potential to innovate when choosing a collaborator for a NPD project. By taking into account the fact that a well-selected partner lead to decrease the risk level and to a better NPD

performance, the originality of this approach is to give to the decision-maker a visibly on criteria to assess possible collaborations.

\section{A. Data on the project, the possible alliances}

In this section, concepts are defined and modelled in the case of an alliance to innovate.

$P$ : a provisional project that consists in achieving a deliverable. $P$ requires an alliance of two firms.

$S C(P)$ : Set of Characteristics (knowledge, technologies, location, size,... ), identified as necessary to answer to the specific need of a $P$.

$a$ : an alliance between two firms $v$ and $w(a=1 \ldots A), A$ being the number of alliance studied with different potential partners for the project.

$V_{v}$ : The vector containing the firm $v$ 's characteristic portfolio. $V_{v}^{z}=1$ if $v$ has the characteristic $z \in S C(P)$. Else $V_{v}^{z}$ $=0$.

$V_{v w}$ : the number of commonalities in $S C$ of two firms $v$ and $w$ for joint innovation, i.e. the number of characteristics known to $v\left(V_{v}^{z}=1\right)$ and to $w\left(V_{w}{ }^{z}=1\right)$.

$S_{v w}$ : the number of complementarities in $S C(P)$ of two firms $v$ and $w$ for joint innovation, i.e. the number of characteristics known by $v$ but not by $w$.

\section{B. Objective function: The innovation potential of the alliance}

The criterion used in this study is the potential to innovate of the alliance for a given NPD project. For successful innovation, firms $\mathrm{v}$ and $\mathrm{w}$ must both be similar to and complement each other [48]. In the case of challenging projects, the alliance should have a good coverage of the required characteristics.

$I P^{a}$ : the Innovation Potential of $a$ for the given project. It depends on three sub criteria (a) the proportion of commonalty, (b) the equivalency in the complementarity and (c) the coverage of SC by $a$. Then:

$$
I P^{a}=\gamma \frac{V_{v w}}{\#\left(V_{v} \cup V_{w}\right)}+\varphi \frac{\min \left(S_{v w} ; S_{w v}\right)}{\max \left(S_{v w} ; S_{w v}\right)}+\lambda \frac{\#\left(V_{v} \cup V_{w}\right)}{\# S C(P)}
$$

(a)

Where $\gamma, \varphi$ and $\lambda$ are three coefficients that are subjectively chosen by the project manager in accordance with the importance of each sub criteria in the context of the project. With $\gamma+\varphi+\lambda=1$.

\section{RESOLUTION APPROACH}

\section{A. Positioning of the proposed work}

The resolution approach developed in this section (Fig. 1) aims helping the Project manager (decision maker) in selecting the best alliance for a given innovative project. The development proposed here are only devoted to collaborative alliances between two partners. 


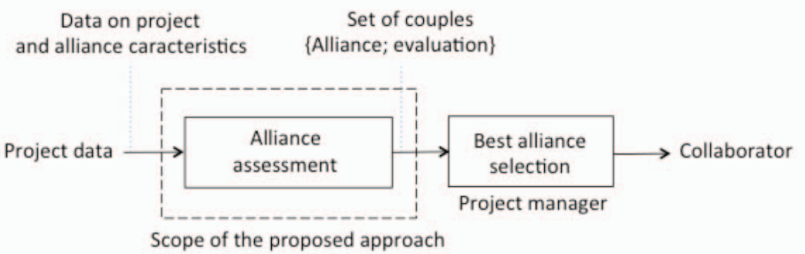

Fig. 1. Overview of the global process of Alliance selection and positioning of our proposed approach

The proposed approach uses project data and potential collaborator information. Based on these data, for each studied alliance, an evaluation of IP is done. Regarding these Couples \{Alliance; evaluation\}, the project manager will make the decision of collaboration.

\section{B. Innovation potential assessment}

A new project can be perceived as being technically rather simple or rather difficult if there are really challenging activities. Moreover, two firms may also have already successfully achieved collaboration but that could be the first collaboration between two partners or having a past common project presenting difficulties.
Therefore, the expert in charge of building the collaboration can have different a perceptions of the respecting importance of each sub criteria composing IPa. Its subjective perception of the technical difficulty of the project and a factual overview of the alliance lead the expert to establish different the weight. A first analysis on how this four kind of context can be perceived and how it influences the weighting of the sub criteria provided in Table 1. Cases SK and SN consider projects rather simple. $\mathrm{CK}$ and $\mathrm{CN}$ consider projects in which there is an important technical challenge.

In case SK it is a matter of carrying out a simple project with a collaborator with whom the company has already worked in the past. This one is well known by the company. The level of confidence in this collaboration is high. The IP index will therefore be based mainly on a complementarity sought between the partners. This is important because it justifies that each partner finds its place in the project. The similarity loses its importance because companies know each other and know how to communicate. The project being simple, if it becomes necessary to develop additional characteristics (skills through trainings,...), the alliance will succeed to do so. Coverage is not a predominant criterion. The IPa index will therefore be calculated by giving a lot of weight to the complementarity between the members of the alliance.

TABLE I. CRITERIA FOCALISATION DEPENDING ON THE CONTEXT

\begin{tabular}{|c|c|c|c|}
\hline & & \multicolumn{2}{|c|}{ Alliance } \\
\hline & & Partner known or past project succeeded & $\begin{array}{l}\text { First collaboration or past project with } \\
\text { difficulties }\end{array}$ \\
\hline \multirow[t]{2}{*}{$\begin{array}{c}\text { Technical } \\
\text { complexity of } \\
\text { the project }\end{array}$} & $\begin{array}{l}\text { Project } \\
\text { technically } \\
\text { simple }\end{array}$ & $\begin{array}{l}\text { (SK) } \\
\text { Confident with the optimist estimation for the } \\
\text { project } \\
\text { Calculate IP knowing that complementarity is } \\
\text { important }\end{array}$ & $\begin{array}{l}\text { (SN) } \\
\text { Confident with the optimist estimation for the } \\
\text { project } \\
\text { Calculate IP knowing that similarity and } \\
\text { complementarity important }\end{array}$ \\
\hline & $\begin{array}{l}\text { High technical } \\
\text { challenges }\end{array}$ & $\begin{array}{l}\text { (CK) } \\
\text { Maximize the margin (budget and time) in case } \\
\text { of difficulties } \\
\text { Calculate IP knowing that complementarity and } \\
\text { coverage important }\end{array}$ & $\begin{array}{l}\text { (CN) } \\
\text { Maximize the margin (budget and time) in case } \\
\text { of difficulties } \\
\text { Calculate IP knowing that similarity, } \\
\text { complementarity and coverage are important }\end{array}$ \\
\hline
\end{tabular}

In case $\mathrm{SN}$ the project is judge simple. Experts are confident in the estimates. However, either it is the first time that companies collaborate either they already try to manage projects without succeeding. In this situation it is important that the companies of the alliance can communicate and understand each other. Therefore, the similarity becomes important. The complementarity remains also important to justify the place of each partner in the alliance. The IPa index will therefore be calculated by giving more weight to the similarity and complementarity.

In cases $\mathrm{CK}$ and $\mathrm{CN}$, there is a real technical challenge to be overcome in the project. In these two cases, the experts will try to maximize the margins to take precautions in case of risk occurrences.

In case $\mathrm{CK}$, the potential collaborator is known. Therefore, similarity is not an important focus (as previously evoked for case SK). On the other hand, it is important that partners be complementary and contributes to the project success. Due to the potential technical difficulties, the coverage should be as high as possible to ensure that the project can be successfully completed.

In case $\mathrm{CN}$, the challenge is important and we rely on collaborators with whom we never work. It is therefore necessary to ensure that the companies are sufficiently similar to be able to understand each other; sufficiently complementary to be able to bring to the project is that the coverage of the project is important to ensure that it is achievable.

In fact it is a continuum that best describes the importance given to the each sub criteria of in the calculation of IPa. Fig 1 gives an overview of their importance depending on the industrial context. 


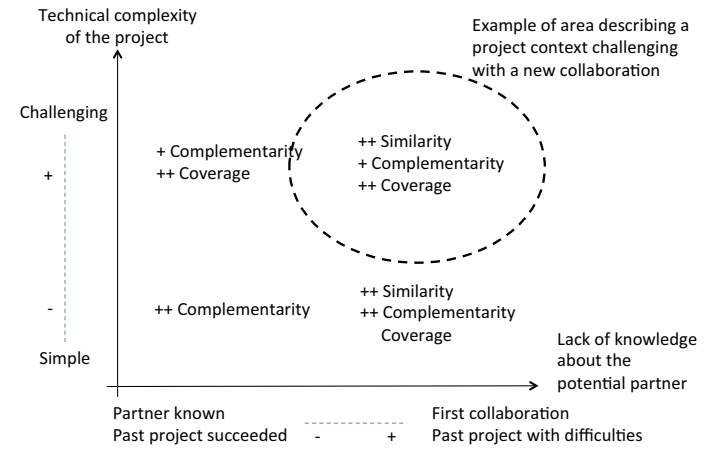

Fig. 2. Weighting of the sub criterion of IPa

\section{ILLUSTRATION ON A DESIGN PROJECT}

The following illustrative case has been developed jointly with our industrial partner, specialized in the aeronautical context. This project is based on a real and current project with respect to the ARP 4754A regulation [53]. In this study, our partner has the role of a Main Company (MC) intended to plan a specific design project.

This project presents significant technical challenges and innovations. MC doesn't have all the characteristics to carry out the project by its own.

\subsection{Presentation of the potential collaborators}

Two potential collaborators are identified (noted A and B). Past projects already have succeeded with A. With this project, that would be the first time that $\mathrm{MC}$ collaborates with $\mathrm{B}$. And the objective of $\mathrm{MC}$ is to select either $\mathrm{A}$ or $\mathrm{B}$ to create an alliance.

Table 2 presents the 16 characteristics required to ideally perform the project (specific means, skills...). The ones provided by Main Company and by each one of the potential partners are also presented. Some characteristics can be provided by one or more potential collaborators, meaning that some similarity can be identified. Some characteristics can be provided only by some potential collaborators meaning that a complementarity is possible. Some characteristics are not provided at all meaning that the coverage will not be full and that these characteristics will have to be developed during the project.

\section{A. Results}

In accordance with the importance of each subcriterion of $\mathrm{IPa}$ in the context of the project, the project manager has to evaluate the coefficients $\gamma, \phi$ and $\lambda$.

Table 3 presents the calculation of the (a) Similarity, the (b) Complementarity and the (c) Coverage based on table 2, as described in equation 1.

Following the analysis presented in table 1 and with respect with $\gamma+\phi+\lambda=1$ coefficients are proposed by MC, in table 4, to weight the sub criterion. For this illustrative case, the approach permits to compute $I P^{a}$ for each industrial context SK to $\mathrm{CN}$.

TABLE II. USEFUL CHARACTERISTICS FOR THE PROJECT

\begin{tabular}{ccccccccccccccccc}
\hline $\boldsymbol{S C}(\boldsymbol{P})$ & 1 & 2 & 3 & 4 & 5 & 6 & 7 & 8 & 9 & 10 & 11 & 12 & 13 & 14 & 15 & 16 \\
\hline $\mathbf{V}_{\mathbf{M C}}$ & $\mathrm{x}$ & $\mathrm{x}$ & & & $\mathrm{x}$ & & & $\mathrm{x}$ & & & $\mathrm{x}$ & & $\mathrm{x}$ & & & $\mathrm{x}$ \\
\hline $\mathbf{V}_{\mathbf{A}}$ & & & $\mathrm{x}$ & $\mathrm{x}$ & $\mathrm{x}$ & & & $\mathrm{x}$ & & & & $\mathrm{x}$ & $\mathrm{x}$ & & $\mathrm{x}$ & $\mathrm{x}$ \\
\hline $\mathbf{V}_{\mathbf{B}}$ & & $\mathrm{x}$ & & $\mathrm{x}$ & $\mathrm{x}$ & & $\mathrm{x}$ & $\mathrm{x}$ & $\mathrm{x}$ & $\mathrm{x}$ & & & & $\mathrm{x}$ \\
\hline
\end{tabular}

TABLE III. CALCULATION OF EACH SUB CRITERION

\begin{tabular}{cccc}
\hline Alliance & $\begin{array}{c}\text { (a) } \\
\text { Similarity }\end{array}$ & $\begin{array}{c}\text { (b) } \\
\text { Complementarity }\end{array}$ & $\begin{array}{c}\text { (c) } \\
\text { Coverage }\end{array}$ \\
\hline $\mathrm{MC}+\mathrm{A}$ & 0,30 & 0,8 & 0,65 \\
$\mathrm{MC}+\mathrm{B}$ & 0,41 & 0,75 & 0,6 \\
\hline
\end{tabular}


TABLE IV. WEIGHTING OF SUB CRITERION AND $I P^{4}$ RESULTS

\begin{tabular}{ccccc}
\hline & \multicolumn{4}{c}{$I P^{a}$} \\
Alliance & Case SK & Case SN & Case CK & Case CN \\
& $(0 ; 1 ; 0)$ & $(0,45 ; 0,45 ; 0,1)$ & $(0 ; 0,4 ; 0,6)$ & $(0,4 ; 0,2 ; 0,4)$ \\
\hline MC+A & 0,8 & 0,56 & $\mathbf{0 , 7 1}$ & 0,54 \\
MC+B & 0,75 & 0,58 & 0,66 & $\mathbf{0 , 5 5}$ \\
\hline
\end{tabular}

Depending on the project context A or B can be preferred. That is mainly due to the fact that $\mathrm{B}$ presents a highest similarity to $\mathrm{MC}$. But A presents a better complementarity to $\mathrm{MC}$ and the coverage of $\mathrm{MC}+\mathrm{A}$ of the required characteristics for the project is higher. This leads naturally to explain why in the case $\mathrm{SN}$ and $\mathrm{CN}$ where project are complex and partners must exchange to overcome the difficulties together, the collaboration $\mathrm{MC}+\mathrm{B}$ presents slightly better results. At the opposite, when projects seem quite simple, a high complementarity influences the assessment. In such case the alliance $\mathrm{MC}+\mathrm{A}$ therefore presents better results.

The fact that the project presents significant technical challenges and innovations leads to use the contextual case CK or $\mathrm{CN}$ to modulate the coefficients $(\gamma ; \phi ; \lambda)$ (i.e. table 1$)$. The fact that MC has already collaborated with A precise the contextual case to $\mathrm{CK}$. The potential to Innovate for this project is therefore assessed to 0,71 .

This project could be the first opportunity for $\mathrm{MC}$ and $\mathrm{B}$ to collaborate. The contextual case is then $\mathrm{CN}$ and the Potential to Innovate for this project is therefore assessed to 0,55 .

The comparison is therefore favourable to the alliance between $\mathrm{MC}$ and $\mathrm{A}$.

\section{B. Discussion}

MC already ran projects in the four industrial contexts evoked in section 4.2. The analysis was done in both way. Which sub criterion is important? What is the influence of the project context to assess the weights? And then, knowing that the weighting is done base on the expert experiences, which past projects can help to assess the weights in each case?

Once results where computed: are the results consistent? Is this consistency due to the correct choice of the sub criterion and of the weights?

In the case SK, projects are mainly oriented to codevelopment with integration at the end. Both partners don't need to precisely know them. Jobs are well done by each partner and there is no need to develop (and spend time or energy) the skills that are well carried on by the partner.

The complementarity is not naturally what company search in a first intention to succeed a complex project. Therefore, this sub criterion can be the most difficult one to be assimilated in the analysis. However by going down deeply in examples of past projects, lot of examples show that complementarity was really important to the success of a project.

In case $\mathrm{CK}$ and $\mathrm{CN}$, the first feeling of the partner was to be afraid to miss a particular characteristic that could be impossible to develop during the project. The first statement was that "if the project is complex, that means that characteristics are really hard to acquire". By going down again to concrete past examples, it appears that this assertion was in part true: when the project is launch, it is difficult to complete the characteristics portfolio. However the success of the project was clearly due to the capacity of partners to communicate to overcome difficulties.

This approach takes up the technical perspective that a project manager or a business manager can have. The results and the recommendations that it brings thus correspond to what could expect of people having this type profile.

In large companies such as our industrial partner, when "technical services" have proposed a company to collaborate, the purchasing department will look for other companies, in a larger perimeter, with the same profile of characteristics. The costs of collaborations will be studied and it is possible that an entirely different company could be retained for collaboration.

\section{CONCLUSIONS}

The choice of partner influences the project, the deliverables, the planning, and therefore it has an effect on the success of innovative project. Partners' experience of the alliance helps in designing and achieving the project. However many estimation are made to build the project.

Each stakeholder can have a factual vision of the characteristics they carry on to the alliance (skills, technical means,...). But it remains difficult to assess the innovation potential of the alliance for a project. Indeed there is a need of assistance to establish this innovative potential of an alliance. This assistance should utilize available data and expertise to give a first view on answer to the following questions: Is the project likely to succeed if we choose to work with a specific partner? Is it more risky to work with this company than with another? Does the fact that a company is partially similar reduces the risk of a project failure? What type of project should be worried if all the characteristics are not covered from the outset by the alliance?

In this paper we propose a model to characterize the contribution of each partner in an alliance to the success of a particular project. We focus on alliances composed by two partners. We consider the similarity of companies, their complementarity and their coverage of the characteristics required for the project. Depending on the fact that the project is judged rather simple or rather difficult and if a collaboration has already been achieved with the studied partner or not, we identify how to weight these specificities to assess an 
innovation potential of an alliance for a given project. Therefore, the proposed approach that allows assessing the potential to innovate and succeed of a given project.

With this help, the decision maker can choose the most appropriate partner using both its factual knowledge of the partners and its subjective perception of the need of the alliance.

A software program can confirm human reasoning but it can't replace the expert and its perception and conviction in decision making to confirm whether a decision is the best one or not. In that way, we illustrate our proposal on a case study, we discuss results in order to improve the understanding of the effect of the similarity, complementarity and coverage on decision in the potential to innovate in different project context.

Next, it becomes necessary to analysis the sensitivity of the approach to the judgmental assessment of the weight of the sub criteria when calculating the potential to innovate. To confirm the feasibility of the project by integrating a more analytic vision of the risk should be done as well. Scenario should be studied and recommendation to manage risk should be made. In that way future works will be focused on how assisting the expert to determine strategies to manage risks.

\section{REFERENCES}

[1] A.K. Gupta and D.L. Wilemon, "Accelerating the development of technology-based new products," California Management Review, vol. 32(2), pp. 24-44, 1990.

[2] M. L. Tushman, "Winning through Innovation," Strategy \& Leadership 25(4), pp. 14-19, 1997

[3] A. Richtnér, P. Åhlström and K. Goffin, "Squeezing R\&D: A Study of organizational slack and knowledge creation in NPD, using the SECI model," Journal of Product Innovation Management, vol. 31(6), pp. $1268-1290,2014$

[4] F. Wohlfeil and O. Terzidis.. "Critical Success Factors for the Strategic Management of Radical Technological Innovation," in IEEE International Conference on Engineering, Technology and Innovation (ICE), pp 1-9, 2014.

[5] R. Cowan and N. Jonard, "Network structure and the diffusion of knowledge," Journal of Economic Dynamics \& Control, vol.28, pp.1557-1575, 2004

[6] T.W. Malone, and R. Laubacher, Inventing the Organizations of the 21st Century, MIT Press, 2003.

[7] C. Edquist, "Systems of Innovation Approaches - Their Emergence and Characteristics." In C. Edquist, Ed., Systems of innovation. Technologies, institutions and organizations. Washington: Pinter, London, pp. 1-35, 1997.

[8] J. A. Baum, T. Calabrese and B.S. Silverman, "Don't go it alone: Alliance network composition and startups' performance in Canadian biotechnology," Strategic management journal vol. 21(3), pp. 267-294, 2000.

[9] J. Hagedoorn, “ Inter-firm R\&D partnerships: An overview of major trends and patterns since 1960," Research Policy, vol. 31(4), pp. 77-92, 2002.

[10] D. Corsaro, and C. Cantù, "Actors' heterogeneity and the context of interaction in affecting innovation networks," Journal of Business \& Industrial Marketing, vol. 30(3/4), pp. 246-258, 2015.

[11] R. Cowan, N. Jonard and J. Zimmermann, "Bilateral collaboration and the emergence of innovation networks," Management Science, vol. 53(7), pp. 1051-1067, 2007.

[12] H. Schiele, "How to distinguish innovative suppliers Identifying innovative suppliers as a new task for purchasing," Industrial Marketing Management, 35 (8), 925-935, 2006.
[13] C. Baldwin and K. Clark, "Managing in an age of modularity," Harvard business Review, in R. Garud, A. Kumaraswamy and R.-N. Langlois Eds., Managing in the modular age, Blackwell Publishing, Oxford, pp. 149-161, 1997.

[14] J. Oh and S.K. Rhee, "Influences of supplier capabilities and collaboration in new car development on competitive advantage of carmakers," Management Decision, vol. 48(5), pp. 756-774, 2010.

[15] K. J. Petersen, R. B. Handfield and G. L. Ragatz, "A model of supplier integration into new product development," Journal of Product Innovation Management, vol. 20(4), pp. 284-299, 2003.

[16] K. T., Ulrich, and S. D. Eppinger, Product design and development. New York: McGraw-Hill Book Co., 2005.

[17] T. E. Johnsen, "Supplier involvement in new product development and innovation: Taking stock and looking to the future," Journal of Purchasing and Supply Management, vol. 15(3), pp. 187-197, 2009.

[18] M. Brettel and N. J. Cleven, "Innovation Culture, Collaboration with external partners and NPD performance: Innovation culture and NPD performance," Creativity and Innovation Management, vol. 20(4), pp.253-272, 2011.

[19] N. J. Pulles, J. Veldman and H. Schiele, "Identifying innovative suppliers in business networks: An empirical study," Industrial Marketing Management, vol. 43(3), pp. 409-418, 2014.

[20] A Cuervo-Cazurra, and C. A. Un, "Why some firms never invest in formal R\&D," Strategic Management Journal, vol. 31(7), pp. 759-779, 2010 .

[21] G. Dosi, "The nature of the innovative process," in: Dosi, G., Freeman, C., Nelson, R., Silverberg, G., Soete, L., Technical Change and Economic Theory, Eds. Pinter, London, pp. 221-238, 1988.

[22] J.A.C. Baum, R. Cowan, N. Jonard, "Network-independent partner selection and the evolution of innovation networks," Managenent Science, vol. 56(11), pp. 2094-2110, 2010.

[23] Z. Emden, R. J. Calantone and C. Droge, "Collaborating for new product development: selecting the partner with maximum potential to create value," The Journal of product innovation management, vol. 23(4), pp. 330-341, 2006.

[24] J. G. March, “ Exploration and exploitation in organisational learning," Organisation Science, vol. 2 (1), pp. 71-87, 1991.

[25] C.K. Prahalad and G. Hamel, "The Core Competence of the Corporation," Harvard Business Review, pp. 79-91, 1990.

[26] J.B. Barney, "Firm resources and sustained competitive advantage," Journal of Management, vol. 17 (1), pp. 99-120, 1991.

[27] H. Linnarsson and A. Werr, "Overcoming the innovation-alliance paradox: a case study of an explorative alliance," European Journal of Innovation Management, vol. 7(1), pp. 45-55, 2004

[28] N. Link and L. L.Bauer, Cooperative Research in U.S. Manufacturing: Assessing Policy Initiatives and Corporate Strategies, Eds. Lexington, MA: Lexington Books, 1989.

[29] J. Bessant, Lamming R, H. Noke and W. Phillips, "Managing innovation beyond the steady state," Technovation, vol. 25(12), pp. 1366-1376, 2005.

[30] T.K. Das, and B.S. Teng, “A risk perception model of alliance structuring," Journal of International Management, vol. 7(1), pp.1-9, 2001.

[31] C. Prange, T. Y. Eng and J. Li, "Collaborative New Product Alliances: A Review of the Literature and Research Perspectives," Strategic Change, vol. 24(4), pp. 351-371, 2015

[32] G. Barczak, A. Griffin and K. B. Kahn, " Perspective: Trends and Drivers of Success in Practices: Results of the 2003 PDMA Best Practices Study, "Journal of Production Innovation Management, vol.26, pp. 3-23, 2009.

[33] T. K. Das and B. S. Teng, "Resource and risk management in the strategic alliance making process," Journal of management, vol. 24(1), pp. 21-42,1998.

[34] C. Araz and I. Ozkarahan, "Supplier Evaluation and Management System for Strategic Sourcing Based on a New Multicriteria Sorting Procedure," International Journal of Production Economics vol. 106 (2), pp 585-606, 2007. 
[35] L. Melander and H. Lopez-Vega, "Impact of Technological Uncertainty in Supplier Selection for NPD Collaborations: Literature Review and a Case Study," International Journal of Technology Intelligence and Planning, vol. 9(4), vol. 323-39, 2013.

[36] Oke, D. I. Prajogo and J. Jayaram, "Strengthening the innovation chain: The role of internal innovation climate and strategic relationships with supply chain partners," Journal of Supply Chain Management, vol. 49(4), pp. 43-58, 2013.

[37] K. Kalaignanam, V. Shankar and R. Varadarajan, "Asymmetric new product development alliances: Win-win or win-lose partnerships?" Management Science, vol. 53(3), pp. 357-374, 2007.

[38] D. Samson and M. Gloet, "Innovation capability in Australian manufacturing organisations: An exploratory study," International Journal of Production Research, vol. 52 (21), pp. 6448-6466, 2014.

[39] J. Howells, D. Gagliardi, and K. Malik, "The Growth and Management of R\&D Outsourcing: Evidence from UK Pharmaceuticals," R\&D Management, vol. 38(2), pp. 205-19, 2008.

[40] B. Feng, Z.-P. Fan, and J. Ma, "A method for partner selection of codevelopment alliances using individual and collaborative utilities." International Journal of Production Economics, vol. 124(1), pp. 159-70, 2010.

[41] T. E. Stuart, "Interorganizational alliances and the performance of firms: A study of growth and innovation rates in a high-technology industry," Strategic management journal, pp. 791-811, 2000.

[42] M. Song and C. A. Di Benedetto, "Supplier's involvement and success of radical new product development in new ventures," Journal of Operations Management, vol. 26(1), pp.1-22, 2008.

[43] M. J. Nieto and L. Santamaria, "The importance of diverse collaborative networks for the novelty of product innovation," Technovation, vol. 27, pp. 367-377, 2007.
[44] R. Adams, J. Bessant, and R. Phelps. "Innovation management measurement: A review," International Journal of Management Reviews 8(1), pp. 21-47, 2006.

[45] B. Nooteboom, W. Van Haverbeke, G. Duijsters, V. Gilsing, and A. Van den Oord, "Optimal cognitive distance and absorptive capacity," Research Policy, vol. 36(7), pp. 1016-1034, 2007.

[46] M.D. Cohen and D.A. Levinthal, "Absorptive capacity: a new perspective on learning and innovation," Administrative Science Quarterly, vol. 35, pp. 128-152, 1990.

[47] L. Alcantara, H. Mitsuhashi and Y. Hoshino, "Legitimacy in international joint ventures: It is still needed," Journal of International Management, vol. 12(4), pp. 389-407, 2006.

[48] R. Cowan, N. Jonard and B. Sanditov, "16 Fits and Misfits Technological Matching and R\&D Networks," in The Economics of Creativity: Ideas, Firms and Markets, vol. 60, pp. 281-308, 2013.

[49] D. Littler, F. Leverick and M. Bruce, "Factors Affecting the Process of Collaborative Product Development: A Study of UK Manufacturers of Information and Communications Technology Products," Journal of Product Innovation Management, vol. 12(1), pp. 16-33, 1995.

[50] E. Sivadas and F. R. Dwyer, "An examination of organizational factors influencing new product success in internal and alliance-based processes," Journal of Marketing, vol. 64(1), pp. 31-49, 2000.

[51] M. Zolghadri, C. Baron and P. Girard. "Innovative Product and Network of Partners Co-Design: Context, Problems, and Some Exploratory Results," Concurrent Engineering, vol. 16(1), pp. 9-21, 2008.

[52] R. N. Osborn and C. C. Baughn, "Forms of inter-organizational governance for multinational alliances," Academy of Management Journal, vol. 33, pp. 503-519, 1990.

[53] SAE ARP4754A. (Aerospace Recommended Practice) Guidelines for Development of Civil Aircraft and Systems 2010. 